\title{
PENGARUH RETURN ON ASSET DAN CURRENT RATIO TERHADAP EARNING PER SHARE (Studi pada PT. PLAZA INDONESIA REALTY, Tbk.)
}

\author{
Oleh : \\ Tri Wartono \\ Dosen Tetap Program Studi Manajemen Universitas Pamulang \\ wartno04@yahoo.com
}

\begin{abstract}
ABSTRAK
Earning Per Share merupakan salah satu indikator yang cukup penting untuk diperhatikan dalam mengambil keputusan sebelum berinvestasi bagi para calon investor untuk menghindari risiko kerugian. Dalam memprediksi Earning Per Share, diperlukan rasio keuangan untuk mengetahui apakah informasi keuangan yang dihasilkan bermanfaat bagi perkembangan Earning Per Share. Penelitian ini bertujuan untuk mengetahui pengaruh Return On Asset (ROA) dan Current Ratio (CR) terhadap Earning Per Share (EPS).

Metode penelitian yang digunakan dalam penelitian ini adalah penelitian kuantitatif. Penelitian ini dilakukan dengan menggunakan data sekunder yang bersumber dari data laporan keuangan laba rugi dan neraca. Analisis statistik yang digunakan dalam penelitian ini adalah asumsi klasik, korelasi, regresi berganda, dan koefisien determinasi serta pengujian hipotesis yang digunakan adalah analisis statistik uji $t$ dan uji $\mathrm{F}$.

Hasil penelitian ini menunjukkan bahwa secara parsial Return On Asset (ROA) dan Current Ratio (CR) berpengaruh signifikan terhadap Earning Per Share (EPS). Hasil lainnya menunjukkan bahwa secara simultan atau bersama-sama Return On Asset (ROA) dan Current Ratio (CR) juga berpengaruh signifikan terhadap Earning Per Share (EPS).
\end{abstract}

\section{Kata Kunci: ROA, CR, dan EPS}

\section{ABSTRACT}

Earning Per Share is one indicator that is important enough to be considered in taking a decision before investing for potential investors to avoid the risk of loss. In predicting Earning Per Share, financial ratios are needed to determine whether the financial information produced is beneficial for the changes of Earning Per Share. This study aims to determine the effect of Return On Assets (ROA) and Current Ratio (CR) to Earning Per Share (EPS).

The research method used in this research is quantitative research. This study was conducted using secondary data sourced from financial statements of income and balance sheet. Statistical analysis used in this research is classical assumption, correlation, multiple regression, and coefficient of determination and hypothesis testing used is $t$ test statistical analysis and $\mathrm{F}$ test.

The results of this study indicate that partially Return On Assets (ROA) and Current Ratio (CR) have a significant effect on Earning Per Share (EPS). Other results indicate that simultaneously or together Return On Assets (ROA) and Current Ratio (CR) also have a significant effect on Earning Per Share (EPS).

Keywords: ROA, CR, and EPS 


\section{PENDAHULUAN}

\section{A. Latar Belakang Masalah}

Perkembangan zaman telah menempatkan pasar modal pada peranan yang semakin penting dalam meningkatkan pertumbuhan ekonomi nasional dan merupakan salah satu sarana terbesar dalam pembentukan modal. Serta tempat mengalokasikan dana yang dapat diarahkan untuk meningkatkan partisipasi masyarakat guna menunjang pembiayaan untuk pembangunan nasional. Sebagian besar negara di dunia memiliki pasar modal, kecuali untuk negara-negara yang belum berbenah dan masih belum mampu melepaskan diri dari masalah ekonomi dan politik. Pasar modal (capital market) merupakan kegiatan yang berkaitan dengan perdagangan efek seperti saham dan obligasi baik untuk jangka pendek maupun jangka panjang antara perusahaan atau lembaga keuangan dengan calon investor.Secara umum pasar modal adalah tempat yang terorganisir, dimana bertemunya pihak yang membutuhkan dana dan pihak yang memiliki dana untuk di investasikan.

Indonesia adalah salah satu negara yang memiliki pasar modal yang saat ini semakin melaju dan berkembang pesat, hal ini terbukti dapat dilihat dengan semakin bertambahnya jumlah saham yang diedarkan dan semakin tingginya jumlah perdagangan saham yang diperdagangkan dalam Bursa Efek Indonesia. Hal ini tentunya dapat menarik minat para pemilik modal dan investor untuk berinvestasi dalam pasar modal. Keberadaan pasar modal disuatu negara bisa menjadi tolak ukur untuk melihat tentang bagaimana kegairahan dan dinamisnya bisnis negara yang bersangkutan dalam menggerakkan berbagai kebijakan ekonomi. Selain itu, pasar modal juga menjadi alternatif para investor atau pemilik modal sebagai salah satu sumber penunjang kemajuan ekonomi suatu negara dan sarana investasi untuk memperoleh keuntungan.Investasi merupakan penanaman modal oleh investor kepada perusahaan yang membutuhkan dana dengan ekspektasi mendapatkan keuntungan atau laba di masa yang akan datang.

Namun, dalam berinvestasi tentu ada sisi buruknya yang sering disebut dengan risk atau resiko. Risk akan selalu ada dalam setiap kegiatan berinvestasi, oleh karena itu investor harus memerlukan sebuah indikator yang cukup penting untuk diperhatikan dalam mengambil keputusan sebelum berinvestasi. Salah satu indikator tersebut adalah Earning per Share. Para calon pemegang saham tertarik dengan Earning per Share yang besar, karena hal ini merupakan salah satu indikator untuk melihat keberhasilan suatu perusahaaan. Earning Per Share (EPS) merupakan salah satu rasio pasar modal, yaitu rasio yang mengukur pendapatan bersih perusahaan dari satu periode dibagi dengan jumlah saham yang beredar. Jika laba per lembar saham tinggi, maka menandakan bahwa perusahaan tersebut mampu memberikan keuntungan yang lebih besar kepada para pemegang saham (investor), hal ini akan berpengaruh pada kenaikan harga saham. Dan sebaliknya, jika laba per lembar saham rendah maka menandakan bahwa perusahaan dapat dikatakan gagal memberikan keuntungan kepada para pemegang saham.

Dengan demikian, semakin besar Earning Per Share (EPS), maka semakin bagus kinerja perusahaan tersebut. Namun, dalam memprediksi Earning Per Share (EPS) kedepan, diperlukan sebuah alat analis untuk mengetahui apakah informasi keuangan yang dihasilkan bermanfaat bagi perkembangan Earning Per Share (EPS). Salah satu alat analisis yang populer adalah analisis rasio keuangan. Rasio dalam analisis 
laporan keuangan adalah angka yang menunjukkan hubungan antara suatu unsur dengan unsur lainnya dalam laporan keuangan. Hubungan antara unsur-unsur laporan keuangan tersebut dinyatakan dalam bentuk matematis yang sederhana (Jumingan 2011:118).

Rasio keuangan yang umumnya digunakan untuk menganalisa keuntungan atau laba perusahaan adalah Return on Asset. Return on Asset (ROA) merupakan salah satu bentuk rasio profitabilitas yang dimaksudkan untuk mengukur kemampuan perusahaan atas keseluruhan dana yang ditanamkan dalam aktivitas yang digunakan untuk aktivitas operasi perusahaan denngan tujuan menghasilkan laba.. Return menggambarkan kondisi yang diharapkan akan diperoleh setelah melakukan tindakan suatu kegiatan investasi. Disamping itu, return menjadi salah satu faktor yang mampu memotivasi investor untuk berinvestasi di pasar modal. Return on Asset (ROA) digunakan untuk melihat sejauh mana investasi yang telah ditanamkan mampu memberikan pengembalian keuntungan sesuai dengan yang diharapkan.(Fahmi, 2012:98). Selain itu, rasio keuangan lainnya yang digunakan untuk menganalisa posisi keuangan perusahaan adalah Current Ratio, yaitu perbandingan antara jumlah aktiva lancar dan hutang lancar. Rasio ini digunakan untuk mengukur kemampuan perusahaan dalam membayar kewajiban jangka pendek atau utang yang segera jatuh tempo pada saat ditagih. Rasio lancar (current ratio)

PT. Plaza Indonesia, Tbk. (PLIN) beroperasi dalam bidang perhotelan, penyewaan ruang pusat perbelanjaan, penyewaan kantor dan apartemen. PLIN melalui anak perusahaan memiliki Hotel Grand Hyatt Jakarta, Pusat Perbelanjaan Plaza Indonesia, The Plaza Office Tower (kantor) serta Keraton At The Plaza (apartemen dan hotel)., Perseroan ini memperoleh Pernyataan Pendaftaran Efektif dari Otoritas Jasa Keuangan (OJK d/h Badan Pengawas Pasar Modal dan Lembaga Keuangan atau Bapepam-LK), yang selanjutnya secara resmi dicatat dalam Bursa Efek Indonesia melalui kode saham PLIN pada Juni 1992. Saham perdana yang ditawarkan sebanyak 35.000 .000 lembar saham dengan nilai nominal Rp. 1.000 per saham dan harga penawaran Rp. 4.950 per saham. Berikut ini tabel perkembangan ROA, Current Ratio dan Earning per Share pada PT. Plaza Indonesia Realty Tbk. periode tahun 2007-2016:

Tabel Perkembangan Return on Asset, Current Ratio dan Earning per Share PT. Plaza Indonesia Realty Tbk.

\begin{tabular}{|c|c|c|c|}
\hline TAHUN & ROA (\%) & CR (\%) & $\begin{array}{c}\text { EPS } \\
\text { (dalam rupiah) }\end{array}$ \\
\hline 2016 & 15,55 & 98,70 & 197,25 \\
\hline 2015 & 6,08 & 175,19 & 78,99 \\
\hline 2014 & 5,11 & 197,97 & 64,80 \\
\hline 2013 & 0,90 & 114,30 & 10,73 \\
\hline 2012 & 5,94 & 144,86 & 66,12 \\
\hline 2011 & 1,96 & 178,00 & 23,41 \\
\hline 2010 & 11,74 & 172,48 & 146,59 \\
\hline 2009 & 6,60 & 86,44 & 82,40 \\
\hline 2008 & $-5,73$ & 121,89 & $-65,68$ \\
\hline 2007 & 3,42 & 433,25 & 28,58 \\
\hline
\end{tabular}

Sumber: Survey Awal 2017 
Berdasarkan latar belakang penelitian yang telah diuraikan di atas, penulis tertarik untuk melakukan penelitian dengan judul "Pengaruh Return on Asset dan Current Ratio terhadap Earning per Share pada PT. Plaza Indonesia Realty Tbk. periode 2007-2016".

\section{B. Perumusan Masalah}

Berdasarkan pada latar belakang yang telah tertulis dan untuk memudahkan dalam pembahasan, maka dibuatlah perumusan masalah sebagai berikut:

1. Bagaimana pengaruh ROA terhadap EPS pada PT. Plaza Indonesia,Tbk.?

2. Bagaimana pengaruh $\mathrm{CR}$ terhadap EPS pada PT. Plaza Indonesia,Tbk.?

3. Bagaimana pengaruh ROA dan $\mathrm{CR}$ terhadap EPS pada PT. Plaza Indonesia, Tbk.?

\section{Tujuan Penelitian}

1. Untuk menanaisis dan mengetahui pengaruh ROA terhadap EPS pada PT. Plaza Indonesia Realty Tbk.

2. Untuk enganaisis dan mengetahui pengaruh CR terhadap EPS pada PT. Plaza Indonesia Realty Tbk.

3. Untuk menganalisis mengetahui pengaruh ROA dan CR terhadap EPS pada PT. Plaza Indonesia Realty Tbk.

\section{TINJAUAN PUSTAKA}

A. Return on Asset (ROA)

ROA merupakan rasio yang digunakan untuk mengukur kemampuan manajemen perusahaan dalam memperoleh keuntungan (laba) secara keseluruhan. Semakin tinggi rasio ini, maka semakin baik produktifitas asset dalam memperoleh keuntungan bersih. Dengan kata lain, semakin besar ROA suatu perusahaan, semakin besar pula tingkat keuntungan yang dicapai perusahaan tersebut dan semakin baik pula posisi perusahaan tersebut dari segi penggunaan asset.

Menurut Prastowo (2011:91), ROA adalah rasio untuk mengukur kemampuan perusahaan dalam memanfaatkan aktivanya untuk memperoleh laba. Rasio ini mengukur tingkat kembalian investasi yang telah dilakukan oleh perusahaan dengan menggunakan seluruh dana (aktiva) yang dimilikinya. Sedangakan menurut Harahap (2010:305) ROA menggambarkan perputaran aktiva diukur dari penjualan. Semakin besar rasio ini maka semakin baik dan hal ini berarti bahwa aktiva dapat lebih cepat berputar dan meraih laba.

Menurut Munawir (2010: 91), terdapat beberapa keunggulan ROA, diantaranya: Sebagai salah satu keunggulan yang prinsipil ialah sifatnya yang menyeluruh. Apabila perusahaan sudah melaksanakan praktek akuntansi yang baik maka manajemen dengan menggunakan teknik analisa ROI dapat mengukur efesiensi penggunaan modal yang bekerja, efesiensi produksi, dan efesiensi bagian penjualan.

Apabila perusahaan dapat mempunyai data industri sehingga dapat diperoleh ratio industry, maka dengan analisa ROI ini dapat dibandingkan efesiensi penggunaan modal pada perusahaannya dengan perusahaan lain yang sejenis, sehingga dapat diketahui apakah perusahaan berada di bawah, 
sama atau di atas rata-rata. Dengan demikian dapat diketahui dimana kelemahan dan apa yang sudah kuat pada perusahaan tersebut dibandingkan dengan perusahaan lain yang sejenis. Dapat digunakan untuk mengukur efesiensi tindakan-tindakan yang dilakukan devisi/bagian, yaitu dengan mengalokasikan semua biaya dan modal ke dalam bagian yang bersangkutan.

Analisa ini dapat digunakan untuk mengukur profitabilitas dari masingmasing produk yang dihasilkan oleh perusahaan. Dengan menggunakan product cost system yang baik, modal dan biaya dapat dialokasikan kepada berbagai produk yang dihasilkan oleh perusahaan yang bersangkutan sehingga dengan demikian akan dapat dihitung profitabilitas dari masing-masing produk. ROI/ROA selain berguna untuk keperluan control, juga berguna untuk keperluan perencanaan. Misalnya ROI dapat digunakan sebagai dasar untuk pengambilan keputusan jika perusahaan akan mengadakan expansi.

Menurut Subramanyam (2013: 242), aset lancar (current asset) adalah kas dan aset lain yang secara wajar dapat direalisasi sebagai kas atau dijual atau digunakan selama satu tahun (atau dalam siklus operasi normal perusahaan jika lebih dari satu tahun). Aset lancar meliputi kas, efek (surat berharga atau sekuritas) yang jatuh tempo dalam satu tahun fiskal ke depan, piutang, persediaan, dan beban dibayar di muka. Kewajiban lancar (current liabilities) merupakan kewajiban yang diharapkan akan dilunasi dalam waktu yang relatif pendek, biasanya satu tahun. Kewajiban lancar meliputi utang usaha, wesel bayar, pinjaman bank jangka pendek, utang pajak, beban yang masih harus dibayar, dan bagian lancar utang jangka panjang (bagian yang jatuh tempo dalam waktu satu tahun).. Adapun rumus yang digunakan untuk menghitung rasio ini adalah:

\section{B. Rasio Lancar (Current Ratio)}

Rasio Lancar atau Current Ratioadalah rasio yang mengukur kinerja keuangan necara likuiditas perusahaan. Rasio Lancar ini menunjukan kemampuan perusahaan untuk memenuhi kewajiban hutang jangka pendeknya pada 12 bulan ke depan. Calon kreditur umumnya menggunakan rasio ini untuk menentukan apakah akan melakukan pinjaman jangka pendek atau tidak kepada perusahaan yang bersangkutan. Rasio Lancar atau Current ratio ini juga menunjukan efisiensi siklus operasi

$$
\text { Current Ratio }=\frac{\text { Aset Lancar }}{\text { Kewajiban Lancar }} \times 100 \%
$$

perusahaan atau kemampuannya mengubah produk menjadi uang tunai. Rasio Lancar dihitung dengan membagikan Aktiva Lancar (current assets) dengan Kewajiban atau Hutang Lancar (current liabilities). Berikut ini adalah rumus rasio lancar:

Rasio Lancar = Aktiva Lancar $/$ Hutang Lancar 


\section{Earning per Share (EPS)}

Menurut Tendelilin (2010:373) komponen penting pertama yang harus diperhatikan dalam analisis perusahaan adalah laba per lembar saham atau lebih dikenal sebagai earning per share (EPS). Informasi EPS suatu perusahaan menunjukkan besarnya laba bersih perusahaan yang siap dibagikan bagi semua pemegang saham perusahaan. Besarnya EPS suatu perusahaan biasa diketahui dari informasi laporan keuangan perusahaan. Meskipun beberapa bersangkutan dalam laporan keuangannya, tetapi besarnya EPS suatu perusahaan bisa kita hitung berdasarkan informasi laporan neraca dan laporan laba rugi laba perusahaan.

Laba per lembar saham dapat mengukur perolehan tiap unit inestasi pada laba bersih badan usaha dalam suatu periode tertentu. Besar kecilnya laba per lembar saham ini dipengaruhi oleh perubahan variabel-variabelnya. Setiap perubahan laba bersih maupun jumlah lembar saham biasa yang beredar dapat mengakibatkan perubahan laba per saham (EPS). EPS adalah variabel yang digunakan untuk mengevaluasi kinerja suatu perusahaan. Variabel ini memungkinkan investor membuat perbandingan yang akurat atas hasil dari perusahaan-perusahaan yang beroperasi disektor dan industri yang berbeda. Adapun perhitungan dari Earning per Share (EPS) adalah sebagai berikut :
$E P=\frac{\text { Laba Bersih }}{\text { Jumlah Lembar Saham yang Beredar }}$

EPS atau pendapatan per lembar saham adalah pemberian keuntungan yang diberikan kepada para pemegang saham dan setiap lembar saham yang dimiliki. Adapun menurut Van Horne dan Wachowicz, EPS adalah "earning after taxes (EAT) devided by the number of common share outstanding".

\section{III.METODE PENELITIAN}

\section{A. Ruang Lingkup Penelitian}

Penelitian yang dilakukan penulis dalam menyusun skripsi ini bersifat deskriptif kuantitatif, yaitu melakukan penelitian dan pembahasan atas permasalahan yang dihadapi perusahaan berdasarkan teori-teori dan penelitian yang sama mendahuluinya terhadap Earning per Share (EPS) perusahaan. Data-data yang disajikan dalam analisa ini menggunakan data yang bersifat kuantitatif atau data-data yang bersifat angka.

B. Objek Penelitian dan Unit Variabel Penelitian

Objek penelitian yang dipilih oleh penulis adalah laporan keuangan PT. Plaza Indonesia Realty, Tbk yang meliputi laporan neraca dan laporan laba rugi yang telah diaudit dan dipublikasikan didalam website resmi 
www.plazaindonesiarealty.com.

Variabel penelitian adalah suatu atribut atau sifat atau nilai dari objek atau kegiatan yang mempunyai variasi tertentu yang ditetapkan oleh peneliti untuk dipelajari dan kemudian ditarik kesimpulannya. Jadi, variabel adalah konsep yang mempunyai bermacam-macam nilai, berupa kuantitatif maupun kualitatif yang nilainya dapat berubah-ubah. Dalam penelitian ini terdapat dua variabel yaitu, variabel independen dan variabel dependen. Variabel independen yang diteliti penulis adalah Return on Asset (ROA) sebagai variabel $\left(\mathrm{X}_{1}\right)$, dan Current Ratio (CR) sebagai variabel $\left(\mathrm{X}_{2}\right)$. Sedangkan variabel dependen adalah Earning per Share (EPS) sebagai variabel terikat $(\mathrm{Y})$

C. Data Penelitian

Peneitian menggunaan data sekunder Data Sekunder yaitu laporan Keuangan yang sudah dipublikasikan dari Bursa Efek Indonesia, hususnya : (1) Laporan keuangan PT. Plaza Indonesia Realty, Tbk tahun 20072016. Dan (2) Data jumlah saham beredar dari kapitalisasi saham tahun 2007-2016.

D. Metode Analisis

Penelitian ini akan dianalisis dengan metode-metode diantaranya adalah:

\section{Analisis Rasio}

Ada beberapa faktor atau rasio yang dapat mempengaruhi besarnya niai EPS suatu perusahaan. Namun, pada penelitian ini penulis memilih menggunakan ROA dan CR dikarenakan dari beberapa sumber referensi kedua variabel tersebut secara teori dikatakan akan mempengaruhi besarnya EPS. Data ROA dan CR yang penulis gunakan merupakan data yang diperoleh dari laporan keuangan PT. Plaza Indonesia Realty, Tbk periode 2007-2016.

2. Analisis Statistik Inferensial

Menurut Sugiyono (2010:148), statistik inferensial merupakan teknik statistik yang berfungsi untuk menganalisis suatu data sampel dan hasilnya diberlakukan untuk populasi. Statistik inferensial diberlakukan untuk seluruh populasi yang didasarkan pada data sampel sehingga kebenarannya disebut dengan peluang. Dalam penelitian ini, analisis data statistik inferensial diukur dengan menggunakan aplikasi SPSS Statistic 20.Uji Asumsi Klasik terdiri dari (1)Uji Normalitas, Uji Multikolinieritas, (3) $\mathrm{Uji}$ Heteroskedastisitas; dan (4) Uji Autokorelasi

\section{Analisis Regresi Linier Berganda}

Analisis regresi berganda adalah analisis untuk mengukur Page | 127 
besarnya pengaruh antara dua atau lebih variabel independen terhadap satu variabel dependen yang sedang diteliti dan dapat pula untuk memprediksi variabel dependen dengan menggunakan variabel independen. Sedangkan menurut Sulisyanto (2011:53) Analisis regresi linier berganda merupakan uji yang dilakukan untuk mengetahui pengaruh dari beberapa variabel independen (X) terhadap variabel dependen (Y). Dalam penelitian ini yang menjadi variabel dependen adalah Earning per Share (Y), sedangkan yang menjadi variabel independen adalah Return on Asset $\left(\mathrm{X}_{1}\right)$ dan Current Ratio $\left(\mathrm{X}_{2}\right)$. Sehingga persamaan regresi yang terbentuk adalah sebagai berikut:

$$
\mathbf{Y}=a+\mathbf{b}_{1} \mathbf{X}_{1}+\mathbf{b}_{2} \mathbf{X}_{2}
$$

\section{Koefisisen Korelasi dan Koefisien Determinasi}

Untuk dapat memahami penafsiran terhadap koefisien korelasi yang ditemukan besar atau kecil, menurut Sugiyono dalam bukunya (Sugiyono, 2012:250), diantaranya:

\begin{tabular}{|c|c|} 
Interprestasi Koefisien Korelasi \\
\hline Interval Koefisien & $\begin{array}{c}\text { Tingkat } \\
\text { Hubungan }\end{array}$ \\
\hline $0,00-0,199$ & $\begin{array}{c}\text { Sangat } \\
\text { Rendah }\end{array}$ \\
\hline $0,20-0,399$ & Rendah \\
\hline $0,40-0,599$ & Sedang \\
\hline $0,60-0,799$ & Kuat \\
\hline $0,80-1,000$ & $\begin{array}{c}\text { Sangat } \\
\text { Kuat }\end{array}$ \\
\hline
\end{tabular}

\section{Uji Hipotesis}

Uji Hipotesis berguna untuk memeriksa atau menguji apakah koefisien regresi yang didapat signifikan (berbeda nyata). Maksud dari signifikan ini adalah suatu nilai koefisien regresi yang secara statistik tidak sama dengan nol, berarti dapat dikatakan bahwa tidak cukup bukti untuk menyatakan variabel bebas mempunyai pengaruh terhadap variabel terikat. Untuk itu maka koefisien regeresi harus diuji. Sedangkan untuk menguji diterima atau ditolaknya suatu hipotesis, maka dilakukan dengan cara sebagai berikut : (1) Uji-t (Uji Parsial) dan (2) Uji-F (Uji Simultan atau bersama).

\section{HASIL ANALISIS DAN PEMBAHASAN}

A. Data Penelitian

\begin{tabular}{|c|c|c|c|c|c|}
\hline \multirow{3}{*}{$\begin{array}{c}\text { TAHU } \\
\mathrm{N}\end{array}$} & \multicolumn{5}{|c|}{ Data Penelitian PT. Plaza Indonesia Realty Tbk. } \\
\hline & \multirow{2}{*}{$\begin{array}{c}\text { LABA } \\
\text { RUGI } \\
\text { EAT } \\
\text { (milyar } \\
\text { rupiah) }\end{array}$} & \multicolumn{3}{|c|}{ NERACA (dalam milyar rupiah) } & \multirow{2}{*}{$\begin{array}{c}\text { Jumlah Saham } \\
\text { Beredar( dalam } \\
\text { juta lembar) }\end{array}$} \\
\hline & & $\begin{array}{l}\text { TOTAL } \\
\text { ASSET }\end{array}$ & $\begin{array}{c}\text { ASET } \\
\text { LANCAR }\end{array}$ & $\begin{array}{l}\text { KEWAJIBA } \\
\text { N LANCAR }\end{array}$ & \\
\hline 2016 & 700,25 & $4,502,12$ & 858,49 & 173,64 & 3,550 \\
\hline 2015 & 280,44 & $4,605,23$ & $1,197,87$ & 527,49 & 3,550, \\
\hline 2014 & 230,07 & $4,495,17$ & $1,143,08$ & 847,18 & 3,550 \\
\hline 2013 & 38,10 & $4,212,48$ & $1,114,85$ & 529,80 & 3,550 \\
\hline 2012 & 234,75 & $3,950,27$ & 966,10 & 367,05 & 3,550 \\
\hline 2011 & 83,13 & $4,432,84$ & 653,35 & 666,92 & 3,550 \\
\hline 2010 & 520,41 & $4,430,89$ & 913,83 & 772,56 & 3,550, \\
\hline 2009 & 292,53 & $4,432,19$ & 730,74 & 577,39 & 3,550 \\
\hline 2008 & 233,16 & $4,070,40$ & 642,98 & 683,74 & 3,550 \\
\hline 2007 & 101,45 & $2,964,66$ & 723,85 & 875,38 & 3,550 \\
\hline
\end{tabular}

B. Analisis Rasio

1. Return on Asset (ROA)

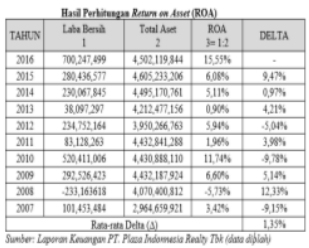




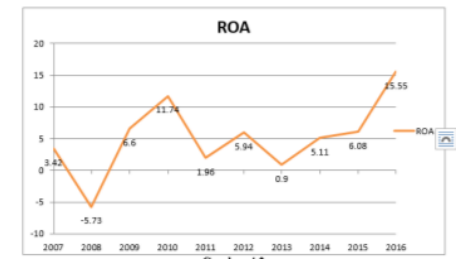

Berdasarkan tabel 4.3 dan gambar 4.2 diatas dapat dilihat bahwa ROA pada PT. Plaza Indonesia Realty, Tbk 2007-2016 cenderung mengelami fluktuatif, pada tahun 2007 ROA sebesar $3,42 \%$ dengan delta sebesar 9,15\% dan terbukti pada tahun 2008 perusahaan mengalami kerugian yang signifikan hingga mencapai $5,73 \%$ dengan delta sebesar $12,33 \%$ tetapi, pada tahun 2009 mampu meningkatkan ROA menjadi $6,6 \%$ dengan jmlah delta sebesar 5,14\%, kemudian pada tahun 2010 ROA mengalami peningkatan yang tajam menjadi $11,74 \%$ dengan delta sebesar $-9,78 \%$, sedangkan ditahun 2011 ROA cenderung melesat turun hingga mencapai angka

2. Current Ratio (CR)

Return On Assets (ROA)
merupakan salah satu rasio
profitabilitas yang digunakan untuk
mengukur efektifitas perusahaan
dalam menghasilkan keuntungan
dengan memanfaatkan total asset
yang dimilikinya. ROA merupakan
rasio antara laba sebelum pajak
terhadap total asset perusahaan
tersebut.

$1,96 \%$ dengan delta sebesar $3,98 \%$, lalu pada tahun 2012 kembali terjadi kenaikan sebesar 5,94\% dengan jumlah delta sebesar $-5,04 \%$, pada tahun 2013 mengalami penurunan sebesar $0,90 \%$ dengan delta sebesar $4,21 \%$, di tahun 2014 mengalami peningkatan hingga mencapai $5,11 \%$ dengan delta sebesar $0,97 \%$, kemudian di tahun 2015 kembali terjadi sedikit peningkatan sebesar $6,08 \%$ dengan jumlah delta $9,47 \%$ dan yang terakhir pada tahun 2016 dimana pada tahun ini terjadi peningkatan yang begitu pesat hingga mencapai angka sebesar $15,55 \%$. Berdasarkan penjelasan diatas, terbukti bahwa ROA mengalami fluktuasi yang cukup signifikan dari tahun 2007-2016.

Current Ratio (CR) atau rasio lancar merupakan rasio yang digunakan untuk mengukur kemampuan perusahaan dalam 
membayar kewajiba jangka pendek atau hutang yang segera hatuh tempo pada saat ditagih secara keseluruhan (Kasmir, 2012:134)

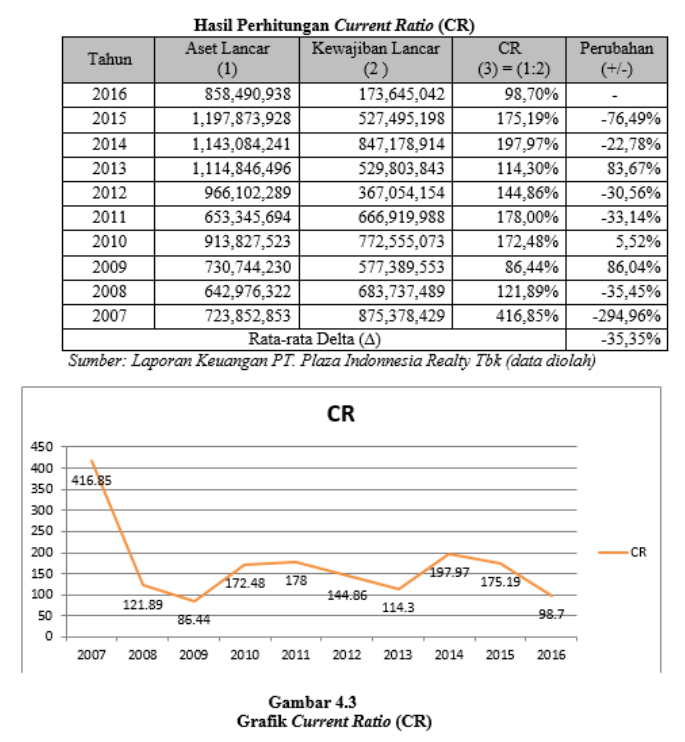

Berdasarkan tabel 4.4 dan gambar 4.3 dapat dilihat bahwa CR pada PT. Plaza Indonesia Realty Tbk. juga cenderung mengalami fluktuasi. Di tahun 2007 CR berada pada posisi yang terbilang cukup baik untuk menyelesaikan kewajiban jangka pendeknya dimana CR memperoleh angka sebesar 416,85\% dengan delta sebesar $-294,96 \%$, tetapi pada tahun 2008 CR mengalami penurunan yang sangat tajam sebesar $121,89 \%$ dengan delta sebesar $-35,45 \%$ dan di tahun 2009 CR kembali mengalami penurunan sebesar $86,44 \%$ dengan delta sebesar $86,04 \%$. Namun, pada tahun 2010 CR mengalami peningkatan yang cukup pesat sebesar
$172,48 \%$ dengan jumlah delta sebesar 5,52\% kemudian di tahun 2011 CR mengalami sedikit peningkatan sebesar $178 \%$ dengan delta sebesar $-33,14 \%$ lalu pada tahun 2012 dan 2013 terjadi kembali penurunan, yaitu pada tahun 2012 berada di angka 144,86\% dengan jumlah delta sebesar $-30,56 \%$ sedangkan pada tahun 2013 berada di angka $114,30 \%$ dengan delta sebesar $83,67 \%$. Namun pada tahun 2014 CR terjadi kenaikan sebesar 197,97\% dengan delta sebesar -22,78\%, lalu kembali mengalami penurunan di tahun 2015 dan 2016, pada tahun 2015 mengalami sedikit penurunan sebesar $175,19 \%$ dengan delta sebesar $-76,14 \%$ sedangkan pada tahun 2016 terjadi penurunan sebesar $98,70 \%$. Berdasarkan penjelasan diatas, kondisi CR sangat tidak stabil karena selalu mengalami fluktuasi.

3. Earning per Share (EPS)

Earning per Share (EPS) merupakan salah satu indikator rasio perusahaa untuk mengukur keberhasilan manajemen dalam mencapai keuntungan bagi pemegang saham. EPS menunjukkan jumlah yang rela dibayarkan oleh investor untuk setiap dolar laba yang dilaporkan (Kasmir,2012,

2


JURNAL

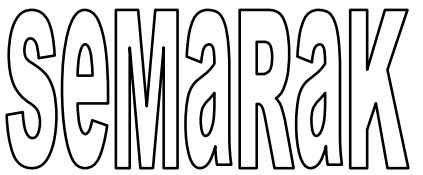

Jurnal Semarak,Vol. 1,No.2,Juni 2018 , Hal (115-134)

@ Prodi Manajemen Fakultas Ekonomi Universitas Pamulang

Hasil Perhitungan Earning per Share (EPS)

\begin{tabular}{|c|c|c|c|c|}
\hline $\begin{array}{c}\text { Tahun } \\
(1)\end{array}$ & $\begin{array}{c}\text { Laba Bersih } \\
(2)\end{array}$ & $\begin{array}{c}\text { Jumlah Saham } \\
\text { Beredar } \\
(3)\end{array}$ & $\begin{array}{c}\text { EPS } \\
(4)=(2: 3)\end{array}$ & $\begin{array}{c}\text { Perubahan } \\
(+/-)\end{array}$ \\
\hline 2016 & $700,247,499$ & $3,550,000,000$ & 197,25 & - \\
\hline 2015 & $280,436,577$ & $3,550,000,000$ & 78,99 & 118,26 \\
\hline 2014 & $230,067,845$ & $3,550,000,000$ & 64,80 & 14,19 \\
\hline 2013 & $38,097,297$ & $3,550,000,000$ & 10,73 & 54,07 \\
\hline 2012 & $234,752,164$ & $3,550,000,000$ & 66,12 & $-55,39$ \\
\hline 2011 & $83,128,263$ & $3,550,000,000$ & 23,41 & 42,71 \\
\hline 2010 & $520,411,006$ & $3,550,000,000$ & 146,59 & $-123,18$ \\
\hline 2009 & $292,526,423$ & $3,550,000,000$ & 82,40 & 64,19 \\
\hline 2008 & $233,163,618$ & $3,550,000,000$ & $-65,68$ & 148,08 \\
\hline 2007 & $101,453,484$ & $3,550,000,000$ & 28,58 & $-94,26$ \\
\hline \multicolumn{5}{|c|}{ Rata-rata Delta $(\Delta)$} \\
\hline
\end{tabular}

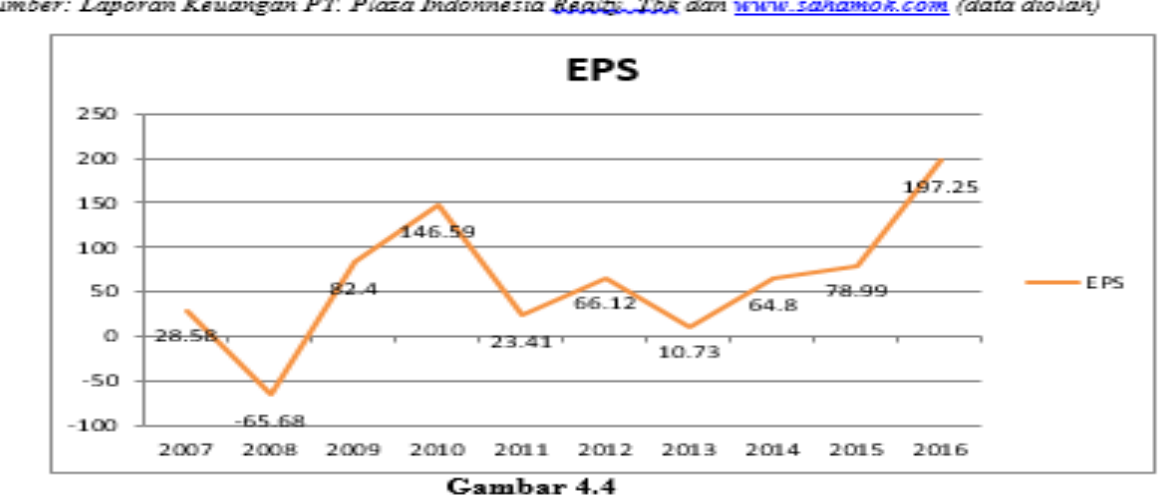

Grafik Earming per Share (EPS)

Rupiah dengan delta sebesar

Berdasakan tabel dan gambar diketahui bahwa EPS PT. Plaza Indonesia Realty Tbk cenderung mengalami fluktuasi. Hal ini dapat dilihat pada tahun 2007 EPS memperoleh angka sebesar 28,58 miliar rupiah dengan delta sebesar 94,26 sementara ditahun 2008 EPS mengalami kerugian sebesar $-65,68$ miliar rupiah dengan delta sebesar 148,08. Namun pada tahun 2009 terjadi kenaikan sebesar 82,40 miliar r
64,19 lalu pada tahun 2010 kembali terjadi kenaikan yang signifikan sebesar 146,59 miliar rupiah dengan delta sebesar -123,18. Kemudian ditahun 2011 EPS mengalami penurunan sebesar 23,41 miliar rupiah dengan delta sebesar 42,71 sedangkan ditahun 2012 EPS mengalami peningkatan dua kali lipat dari tahun sebelumnya sebesar 66,12 miliar rupiah dengan delta sebesar -55,39. Tetapi, pada tahun 2013 terjadi penurunan yang sangat pesat mencapai 10,73 miliar rupiah dengan delta sebesar 54,07. Namun pada tahun 2014 EPS meningkat pesat hingga menembus angka 64,8 miliar rupiah dengan delta $-14,19$ lalu pada tahun 2015 kembali terjadi kenaikan sebesar 78,99 miliar rupiah dengan delta sebesar 118,26. Dan pada tahun 2016 EPS mengalami peningkatan yang sangat signifikan yaitu sebesar 197,25 miliar rupiah. 

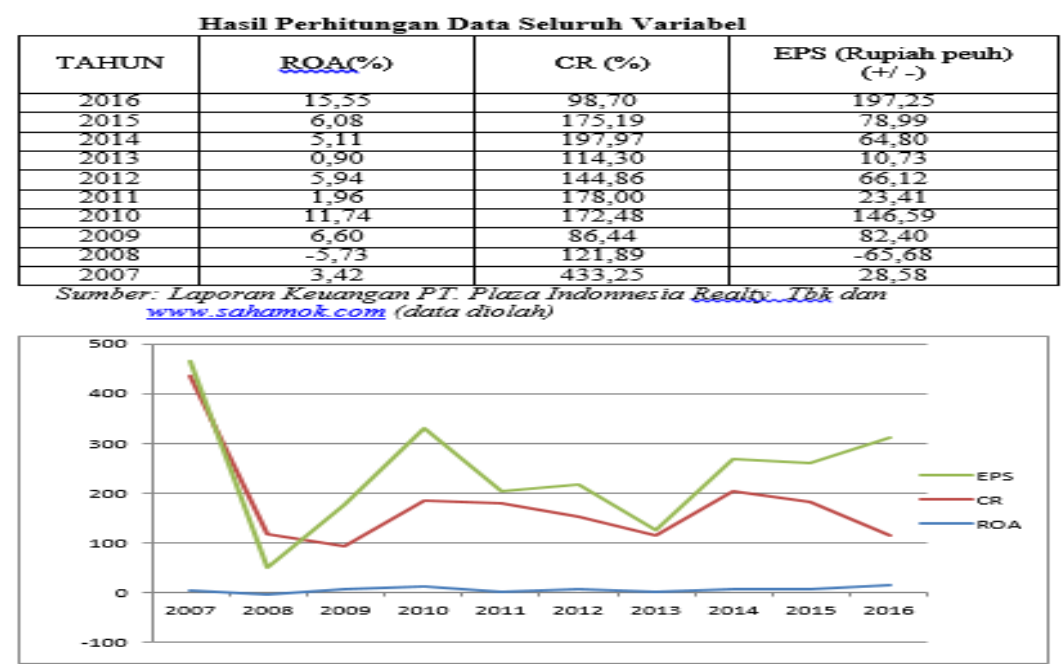

C. Analisis Statistik Inferensial

1. Uji Asumsi Klasik

Asumsi regresi pada dasarnya adalah studi ketergantungan variabel bebas (independent) pada satu atau lebih variabel penjelas atau terikat (dependen) dengan maksud untuk mengestimasikan atau menaksir rata-rata populasi atau nilai rata-rata variabel dependen berdasarkan nilai variabel independen. On Asset (ROA) dan Current Ratio (CR).

\section{a. Uji Normalitas}

Uji normalitas bertujuan untuk menguji kenormalan dalam model regresi, variabel dependen dan variabel independen mempunyai distribusi normal atau tidak. Model regresi yang terbaik adalah yang terdistribusi secara normal atau mendekati normal.

Hasil Uji Normalitas One-Sample Kolmogorov-Smirnov Test

\begin{tabular}{|c|c|c|}
\hline & & $\begin{array}{l}\text { Unstandardized } \\
\text { Residual }\end{array}$ \\
\hline \multicolumn{2}{|l|}{$\mathrm{N}$} & 10 \\
\hline Normal Parametersa,b & Mean & $0 \mathrm{E}-7$ \\
\hline & Std. Deviation & 3,83916330 \\
\hline Most Extreme & Absolute & 184 \\
\hline Differences & $\begin{array}{l}\text { Positive } \\
\text { Negative }\end{array}$ & $\begin{array}{r}, 123 \\
-, 184\end{array}$ \\
\hline Kolmogorov-Smirnov Z & & ,581 \\
\hline Asymp. Sig. (2-tailed) & & ,889 \\
\hline
\end{tabular}




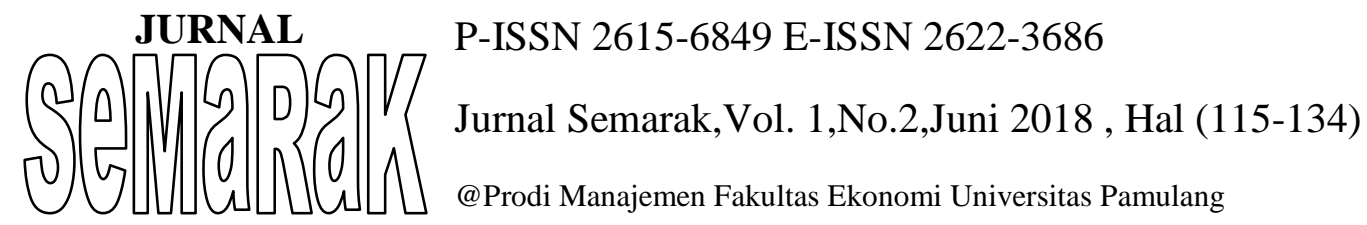

Berdasarkan tabel diatas hasil uji normalitas dengan uji statistik Kolmogorov-Smirnov Test diatas menunjukkan hasil bahwa nilai signifikan (Asymp.sig.(2-tailed) sebesar 0,889 mendekati 1 yang berarti bahwa data yang digunakan dalam penelitian ini berdistribusi normal.

\section{b. Uji Multikolinieritas}

Bertujuan untuk menguji apakah pada model regresi ditemukan adanya korelasi antara korelasi antara variabel independen. Modal regresi yang baik seharusnya tidak terjadi korelasi diantara variabel independen. Multikolinearitas dapat juga dilihat dari nilai Tolerance (TOL) dan metode VIF (Varians Inflation Factor).

\section{Hasil Uji Multikolinieritas}

\begin{tabular}{|cc|c|c|}
\hline \multirow{2}{*}{ Model } & \multicolumn{2}{|c|}{ Collinearity Statistics } \\
\cline { 3 - 4 } & ROA & Tolerance & VIF \\
\hline \multirow{2}{*}{1} &, 987 & 1,013 \\
& CR &, 987 & 1,013 \\
\hline \multicolumn{3}{|c|}{ a. Dependent Variable: ROA } \\
\multicolumn{3}{|c}{ Sumber: Data diolah menggunakan } \\
\multicolumn{3}{c}{ SPSS 20.0}
\end{tabular}

Berdasarkan tabel 4.8 diatas menunjukkan bahwa nilai tolerance untuk masing-masing variabel independen Return on Asset (ROA) dan Current Ratio (CR) sebesar 0,987 artinya lebih dari $0,1 \quad(>0,1)$ dan nilai VIF (Variance Inflation Factor) untuk variabel independen Return on Asset (ROA) dan Current Ratio (CR) yaitu sebesar 1,013 artinya kurang dari 10 $(<10)$. Maka dapat disimpulkan bahwa dalam penelitian ini tidak terjadi masalah multikolinieritas atau tidak ada hubungan yang terjadi antara variabel independen satu dengan variabel independen lainnya.

\section{c. Uji Heteroskedastisitas}

Uji heteroskedastisitas bertujuan menguji apakah dalam model regresi terjadi ketidaksamaan varian dari residual satu pengamatan ke pengamatan yang lain. Jika varian tetap maka disebut homoskedastisitas dan jika berbeda maka terjadi problem heteroskedastisitas.

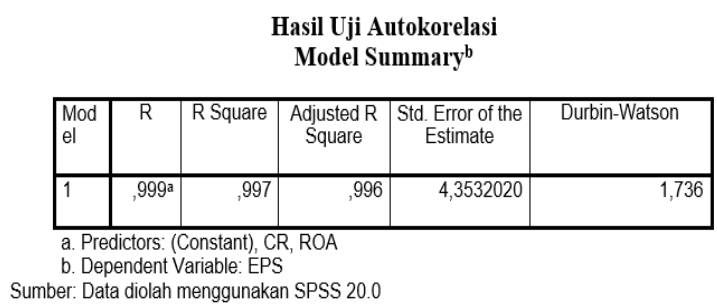

Untuk itu perlu adanya deteksi mengenai ada tidaknya sifat heteroskedastisitas dalam data. Uji heteroskesdastisitas dilakukan dengan metode grafik plot, yaitu jika titik-titik menyebar secara acak dan tidak berkumpul pada satu tempat, maka dapat disimpulkan tidak terjadi masalah heteroskedastisitas. Perhitungan hasil Uji Heteroskedastisitas dalam penelitian ini dapat dilihat pada gambar dibawah ini 


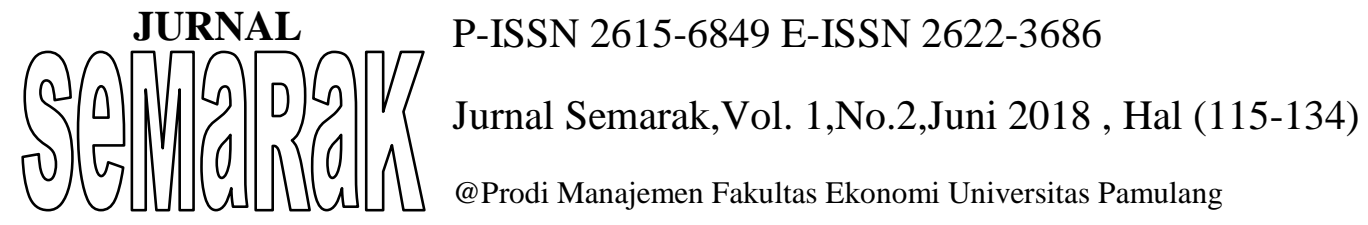

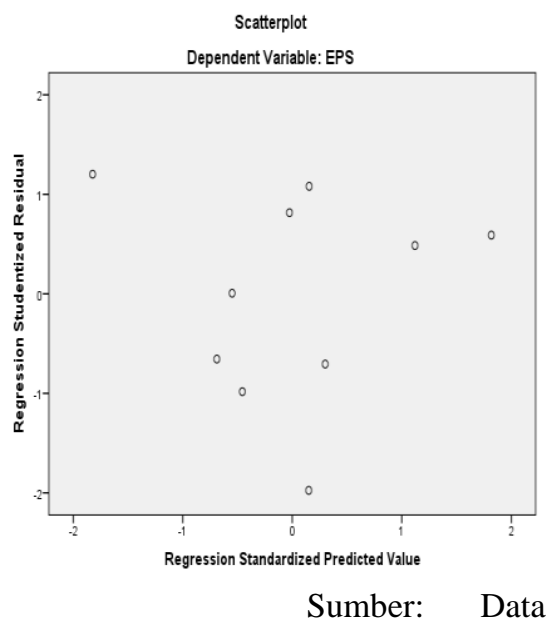

diolah menggunakan SPSS 20.0

\section{Gambar 4.6 \\ Hasil Uji Heteroskedastisitas}

Berdasarkan gambar 4.6 hasil uji heteroskedastisitas menunjukkan bahwa adanya hubungan antara variabel independent dengan variabel dependent karena dapat dilihat bahwa sebaran datanya berpencar disekitar angka nol dan tidak membentuk suatu pola atau kecenderungan tertentu. Maka dapat disimpulkan bahwa data ini telah layak memenuhi syarat untuk memprediksi.

Berdasarkan hasil uji autokorelasi diatas, diketahui nilai Durbin Watson adalah 1,736 nilai ini akan dibandingkan dengan nilai tabel signifikan 5\% $(0,05)$ dengan jumlah sample $\mathrm{n}=$ 10 dan jumlah variabel independen $2(\mathrm{~K}=2)=2.10$ maka diperoleh nilai dU 1,6413. Nilai Durbin Watson 1,736 lebih besar dari nilai dU $(1,6413)$ artinya tidak ada autokorelasi. Sehingga sebelum menggunakan analisis regresi berganda data tidak perlu terlebih dahulu ditransformasi.

D. Uji Regresi Linier Berganda

Analisis regresi linier berganda merupakan uji yang dilakukan untuk mengetahui pengaruh dari beberapa variabel independen (X) terhadap variabel dependen (Y). Dalam penelitian ini uji analisis regresi berganda dapat digunakan untuk menganalisis pengaruh variabel independent yaitu Return on Assets (ROA) dan Current Ratio (CR) terhadap variabel dependent yaitu Earning per Share (EPS). Perhitungan hasil uji regresi linier berganda dalam penelitian ini dapat dilihat dibawah

Dari output diatas, diperoleh nilai a (konstanta) sebesar 7,513, nilai ROA sebesar 1238,330 dan nilai CR sebesar 4,719. Dengan demikian maka dapat dibentuk persamaan regresi linier berganda sebagai berikutDari hasil persamaan regresi linier berganda tersebut, masing-masing variabel dapat diinterpretasikan pengaruhnya terhadap Earning per Share sebagai berikut:

$$
Y=7,513+1238,330 X_{1}-4,719 X_{2}
$$

\section{a. Konstanta}

Nilai konstanta berada pada positif 7,513 yang menunjukkan apabila variabel Return on Asset (ROA) dan Current Ratio (CR) tidak ada perubahan atau sama dengan 0 (nol) maka akan meningkatkan Earning per Share (EPS) sebesar Rp. 7,513. 


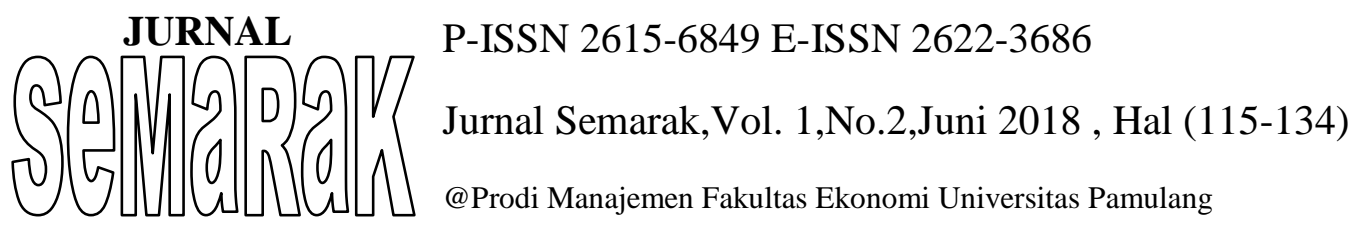

b. Return on Asset (ROA) $\left(\mathrm{X}_{1}\right)$ terhadap Earning per Share (EPS) (Y)

Nilai koefisien Regresi untuk $\operatorname{ROA}\left(\mathrm{X}_{1)}\right.$ sebesar 12,38 dan bertanda positif. Hal ini mengandung arti bahwa setiap kenaikan Return on Asset (ROA) $1 \%$, maka Earning per Share (EPS) akan naik sebesar Rp. $12, .38$.

c. $\quad$ Current Ratio (CR) $\left(\mathrm{X}_{2}\right)$ terhadap Earning per Share (EPS) (Y)

Nilai koefisien Current Ratio (CR) untuk variabel $\mathrm{X}_{2}$ sebesar 4,719 dan bertanda negatif. Hal ini mengandung arti bahwa setiap kenaikan Current Ratio (CR) 1\% ) maka Earning per Share (EPS) akan turun sebesar Rp.-4,719.Uji Koefisien Korelasi dan Koefisien Determinasi

Analisis ini digunakan untuk mengetahui hubungan antara dua atau lebuh variabel independen $\left(\mathrm{X}_{1}\right.$,

Hasil Uji Regresi Linier Berganda
Coefficients $^{\mathbf{a}}$
\begin{tabular}{|c|c|c|c|c|c|}
\hline Model & \multicolumn{2}{|l|}{ Unstandardized Coefficients } & $\begin{array}{c}\text { Standardized } \\
\text { Coefficients }\end{array}$ & T & Sig. \\
& & & & \\
\cline { 2 - 5 } & B & Std. Error & Beta & & \\
\hline (Constant) & 7,513 & 3,367 & & 2,232 &, 061 \\
ROA & 12,383 & 25,094 &, 990 & 49,347 &, 000 \\
CR & $-4,719$ & 1,550 & -.061 & $-3,046$ &, 019 \\
\hline
\end{tabular}

a. Dependent Variable: EPS

Sumber: Data diolah menggunakan SPSS 20.0

$\left.\mathrm{X}_{2}, \quad \ldots \quad \mathrm{X}_{\mathrm{n}}\right)$ terhadap variabel dependen (Y) secara serentak.

Berdasarkan tabel 4.12 pada tabel uji koefisien korelasi diatas, dapat dilihat bahwa antara variabel $\operatorname{ROA}\left(\mathrm{X}_{1}\right)$ dan $\mathrm{CR}\left(\mathrm{X}_{2}\right)$ terdapat koefisien korelasi (r) sebesar $-0,112$ dengan tingkat signifikansi 0,757 .
Hal ini berarti bahwa ada korelasi negatif antara ROA dan CR dengan tingkat hubunan sangat lemah dan korelasi tersebut tidak signifikan karena $\mathrm{p}>0,05(0,757>0,05)$. Dapat dilihat juga bahwa antara $\operatorname{ROA}\left(\mathrm{X}_{1}\right)$ dengan EPS(Y) terdapat koefisien korelasi (r) sebesar 0,997 dengan tingkat signifikansi 0,000. Hal ini berarti bahwa ada korelasi positif antara ROA dengan EPS dengan tingkat hubungan sangat kuat dan korelasi tersebut signifikan karena $\mathrm{p}<0,01(0,000<0,01)$. Dan antara $\mathrm{CR}\left(\mathrm{X}_{2}\right)$ dengan $\mathrm{EPS}(\mathrm{Y})$ terdapat koefisien korelasi (r) sebesar $-0,172$ dengan tingkat signifikansi 0,634 . HaL ini berarti bahwa ada korelasi negatif antara CR dengan EPS dengan tingkat hubungan sangat lemah dan korelasi tersebut tidak signifikan karena $\mathrm{p}>0,05(0,634>$ $0,05)$

Koefisien determinasi $\left(\mathrm{R}^{2}\right)$ digunakan untuk mengukur seberapa jauh kemampuan model menerangkan variasi variabel dependen. Besarnya nilai koefisien determinasi adalah antara nol (0) sampai dengan satu (1). Semakin besar nilai $\mathrm{R}^{2}$ maka semakin baik hasil dari model regresi tersebut. Dari hasil pengolahan data, dapat diperoleh hasil sebagai berikut:

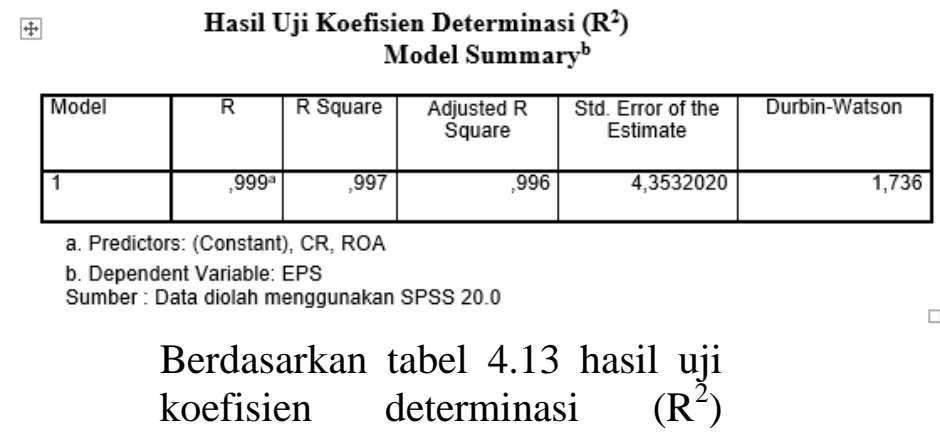

Page | 131 
menunjukan bahwa nilai Adjusted R Square sebesar 0,996 atau sebesar $99,6 \%$ yang berarti bahwa variabel independen yang terdiri dari Return on Asset (ROA) dan Current Ratio (CR) memberikan kontribusi yang kuat terhadap Earning per Share (EPS) sebesar 99,6\% sedangkan sisanya sebesar $0,4 \%$ dipengaruhi oleh variabel atau faktor-faktor lain yang tidak dijelaskan dalam penelitian ini.

E. Uji Hipotesis

Uji Hipotesis berguna untuk memeriksa atau menguji apakah koefisien regresi yang didapat signifikan (berbeda nyata). Maksud dari signifikan ini adalah suatu nilai koefisien regresi yang secara statistik tidak sama dengan nol, berarti dapat dikatakan bahwa tidak cukup bukti untuk menyatakan variabel bebas mempunyai pengaruh terhadap variabel terikat. Untuk itu maka koefisien regeresi harus diuji. Sedangkan untuk menguji diterima atau ditolaknya suatu hipotesis, maka dilakukan dengan cara sebagai berikut :

\section{a. Uji t (Uji Parsial)}

Uji $\mathrm{t}$ bertujuan untuk menguji pengaruh masing-masing variabel independen Return on Asset (X1) dan Current Ratio (X2) dan variabel dependen Earning per Share

Hasil Uji t (Uji Parsial)

Coefficients $^{a}$

\begin{tabular}{|c|c|c|c|c|c|}
\hline \multirow{2}{*}{ Model } & \multicolumn{2}{|l|}{ Unstandardized Coefficients } & $\begin{array}{c}\text { Standardized } \\
\text { Coefficients }\end{array}$ & & S \\
\cline { 2 - 4 } & B & Std. Error & Beta & & \\
\hline (Constant) & 7,513 & 3,367 & & 2,232 &, 061 \\
ROA & 1238,330 & 25,094 &, 990 & 49,347 &, 000 \\
CR & $-4,719$ & 1,550 &,- 061 & $-3,046$ &, 019 \\
\hline
\end{tabular}

a. Dependent Variable: EPS

Sumber: Data diolah menggunakan SPSS 20.0
(Y). Berikut disajikan uji hipotesis menggunakan uji t, dengan pengujian $\mathrm{H}_{0}$ diterima bila $t_{\text {hitung }}<t_{\text {tabel }}$ dan $\mathrm{H}_{0}$ ditolak bila $t_{\text {hitung }}>t_{\text {tabel }}$

1) Jika $t_{\text {hitung }}>t_{\text {tabel }}$ maka variabel bebas berpengaruh terhadap variabel terikat.

2) Jika $t_{\text {hitung }}<t_{\text {tabel }}$ maka variabel bebas tidak berpengaruh terhadap variabel terikat.

Untuk pengujian berdasarkan nilai signifikansi hasil output SPSS:

1) Jika nilai signifikan $<0,05$ atau 5\% maka hipotesis yang diajukan diterima atau dikatakan signifikan.

2) Jika nilai signifikan $>0,05$ atau 5\% maka hipotesis yang diajukan ditolak atau dikatakan tidak signifikan.

Uji $\mathrm{t}$ dilakukan dengan menggunakan uji 2 arah dengan $\alpha=5 \%$, sehingga $\mathrm{t}$ tabel diperoleh sebagai berikut:

$$
\begin{aligned}
& =t\left\{\frac{\alpha}{2}=(n-k-1)\right\} \\
& =t\left\{\frac{0,05}{2} ; d f=(10-2-1)\right\} \\
& =t(0,025: 7) \\
& =2,364
\end{aligned}
$$


Berdasarkan tabel 4.14 menunjukkan bahwa Return on Asset (ROA) memiliki thitung sebesar 49,347 sedangkan $t_{\text {tabel }}$ sebesar 2,364 sehingga $t_{\text {hitung }}>t_{\text {tabel }}$ dengan probabilitas signifikan untuk variabel Return on Asset (ROA) sebesar 0,000 lebih kecil dari taraf signifikan yang ditentukan yaitu sebesar 0,05 . Dengan demikian maka $\mathrm{H}_{\mathrm{o}}$ ditolak dan $\mathrm{H}_{\mathrm{a} 1}$ diterima sehingga dapat disimpulkan bahwa secara parsial Return on Asset (ROA) berpengaruh signifikan terhadap Earning per Share (EPS).

Current Ratio (CR) memiliki $t_{\text {hitung }}$ sebesar $\quad-3,046$ sedangkan $t_{\text {tabel }}$ sebesar 2,364 sehingga $t_{\text {hitung }}>t_{\text {tabel }}$ dengan probabilitas signifikan untuk variabel Current Ratio (CR) 0,019 lebih kecil dari taraf signifikan yang ditentukan yaitu sebesar 0,05. Dengan demikian maka $\mathrm{H}_{\mathrm{o}}$ ditolak dan $\mathrm{H}_{\mathrm{a} 2}$ diterima sehingga dapat disimpulkan bahwa secara parsial Current Ratio (CR) berpengaruh signifikan terhadap Earning per Share (EPS).

\section{b. Uji F (Uji Simultan)}

Menurut Priyatno (2012:55), Uji $\mathrm{F}$ digunakan untuk menguji pengaruh variabel independen secara bersama-sama terhadap variabel dependen. Tahap - tahap pengujian statistik $\mathrm{F}$ adalah sebagai berikut:
1) Menentukan hipotesis nol dan hipotesis alternative $\mathrm{H}_{\mathrm{o}}$ : Artinya Return on Asset (ROA) dan Current Ratio (CR) tidak berpengaruh terhadap Earning per Share (EPS)

$\mathrm{H}_{\mathrm{a}}$ : Artinya Return on Asset (ROA) dan Current Ratio (CR) berpengaruh terhadap Earning per Share (EPS).

2) Menentukan taraf signifikansi, dalam pengertian ini taraf signifikansi yang digunakan sebesar 0,05.

3) Menentukan $F_{\text {hitung }}$ dan $F_{\text {tabel }}, F_{\text {hitung }}$ dapat dilihat pada tabel ANOVA hasil perhitungan dengan menggunakan SPSS versi 20 yaitu sebesar 1254,976 dan $F_{\text {tabel }}$ dapat dicari pada tabel uji $F$ dengan signifikansi 0,05 .

$=f(k: n-k)$

$=f(2: 10-2)$

$=f(2: 8)$

$=4,46$

Maka nilai $F_{\text {tabel }}$ yang didapat adalah sebesar 4,46.

4) Pengambilan

keputusan

Jika $F_{\text {hitung }}<\mathrm{F}_{\text {tabel }}$ maka Ho diterima dan Ha ditolak

Jika $F_{\text {hitung }}>F_{\text {tabel }}$ maka Ho ditolak dan Ha diterima 


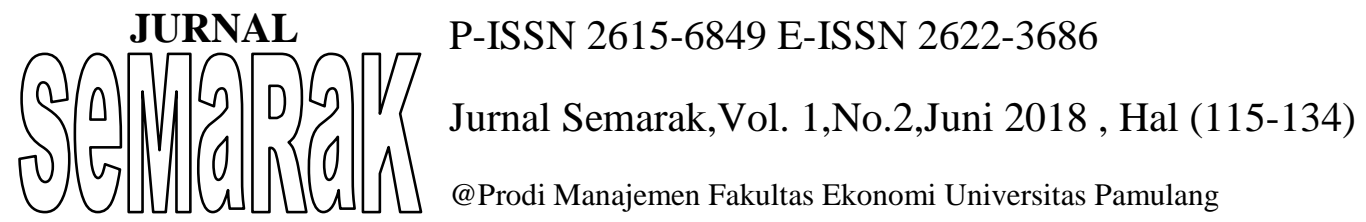

Berdasarkan tabel 4.15 menunjukkan bahwa nilai $\mathrm{F}_{\text {hitung }}$ yang diperoleh sebesar $1254,976>$ nilai $F_{\text {tabel }}$ yaitu sebesar 4,46 Sehingga $F_{\text {hitung }}$ $1254,976>F_{\text {tabel }} 4,46$. Dengan demikian maka $\mathrm{H}_{\mathrm{o}}$ ditolak dan $\mathrm{H}_{\mathrm{a} 3}$ diterima yang berarti terdapat pengaruh signifikan antara Return on Asset (ROA) dan Current Ratio (CR) secara simultan atau bersama-sama terhadap Earning per Share (EPS). Dari tabel diatas juga dapat dilihat bahwa tingkat signifikan sebesar 0,000 lebih kecil dari taraf signifikan yang ditentukan $\alpha=0,05$ maka mengindikasi bahwa Return on Asset (ROA) dan Current Ratio (CR) secara bersama-sama berpengaruh signifikan terhadap Earning per Share (EPS).

\section{KESIMPULAN DAN SARAN}

A. Kesimpulan

Berdasarkan hasil pengujian dan pembahasan mengenai pengaruh variabel independen Return on Asset (ROA) dan Current Ratio (CR) terhadap Earning per Share (EPS) sebagai variabel dependen pada PT. Plaza Indonesia Realty Tbk maka dapat ditarik beberapa kesimpulan sebagai berikut:
1. Return on Asset (ROA) terhadap Earning per Share (EPS) pada PT. Plaza Indonesia Realty, Tbk berpengaruh signifikan secara parsial (uji t) yang dapat dilihat dari taraf signifikansi Return on Asset (ROA) terhadap Earning per Share (EPS) menunjukkan hasil $t_{\text {hitung }} 49,347>t_{\text {tabel }}$ 2,364 dengan taraf signifikansi $0,000<0,05$.

2. Current Ratio (CR) terhadap Earning per Share (EPS) pada PT. Plaza Indonesia Realty, Tbk berpengaruh signifikan secara parsial (uji t) yang dapat dilihat dari taraf signifikansi Current Ratio (CR) terhadap Earning per Share (EPS) menunjukkan hasil $\mathrm{t}_{\text {hitung }} 3,046>\mathrm{t}_{\text {tabel }} 2,364$ dengan taraf signifikansi $0,019<0,05$.

3. Return on Asset (ROA) dan Current Ratio (CR) terhadap Earning per Share (EPS) pada PT. Plaza Indonesia Realty, Tbk berpengaruh secara simultan atau bersama-sama berpengaruh positif signifikan yang dapat dilihat dari hasil uji $F$. Berdasarkan hasil uji F maka, Page | 132 
hasil $\mathrm{F}_{\text {hitung }} 1254,976>\mathrm{F}_{\text {tabel }}$ 4,46 dengan taraf signifikansi sebesar $0,061<0,05$.

B. Saran

PT. Plaza Indonesia Realty, Tbk harus dapat memaksimalkan nilai laba perusahaan agar dapat meningkatkan perolehan profitabilitas pada tahun-tahun mendatang. Dan apabila terjadi penurunan nilai laba tersebut maka perlu diketahui faktorfaktor apa saja yang menyebabkan penurunan sehingga dapat segera diatasi guna meningkatkan profitabilitas selanjutnya.

PT. Plaza Indonesia Realty, Tbk harus dapat menurunkan Current Ratio (CR) perusahaan, karena jika semakin besar Current Ratio (CR) maka semakin rendah kemampuan perusahaan untuk menutupi kewajiban jangka pendeknya dan dapat mengakibatkan perusahaan gagal membayar kewajiban tersebut.

PT Plaza Indonesia Realty, Tbk harus dapat lebih memperhatikan nilai Earning per Share (EPS) karena semakin tinggi Earning per Share (EPS) maka, laba yang akan diterima oleh para investor dan perusahaan semakin tinggi pula. Hal ini akan membuat para investor semakin tertarik untuk membeli saham dan menyebabkan keuntungan pada perusahaan meningkat.

\section{DAFTAR PUSTAKA}

Brigham, Eugene F. dan Houston, Joel F. (2010).Dasar-Dasar Manjemen Keuangan. Edisi Sebelas Buku Satu. Jakarta: Salemba Empat.

Irham, Fahmi. (2011). Analisis Laporan Keuangan. Bandung: ALFABETA.

Irham, Fahmi. (2012). Pengantar Pasar Modal. Cetakan Pertama. Bandung: ALFABETA.

Jumingan. 2011. Analisis Laporan Keuangan. Cetakan ke Empat. Jakarta: PT Bumi Aksara.

Kasmir.(2012). Analisis Laporan Keuangan. Jakarta: PT. Raja Grafindo Persada.

Syamsuddin, Lukman. (2011). Manajemen Keuangan Perusahaan. Jakarta: Rajawali Pers.

Munawir, S. Drs. (2010). Analisa Laporan Keuangan. Yogyakarta: Liberty.

Sugiyono. (2011). Metode Penelitian Kuantitatif Kualitatif RND (Cetakan ke 14). Bandung: Alfabeta 


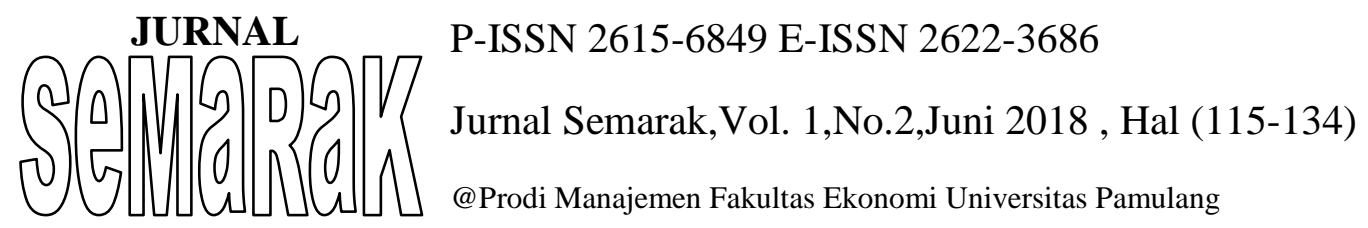

Terry, George dan Lislie W. Rue. (2010). Dasar-Dasar Manajemen. Cetakan Kesebelas. Jakarta: PT. Bumi Aksara

Wijayanto, Dian. (2012). Pengantar Manajemen. Jakarta: Gramedia Pustaka Utama.

Hasibuan, Malayu S.P. (2014). Manajemen Sumber Daya Manusia (Edisi Revisi). Jakarta: PT. Bumi Aksara.

Seputra, Yulius Eka Agung. (2014). Manajemen Dan Perilaku Organisasi. Yogyakarta: Graha Ilmu.

Fahmi, Irham. (2014). Analisis Laporan Keuangan. Bandung: Alfabeta.

Riyanto, Bambang. (2012). Dasar-Dasar Pembelanjaan Edisi 4. Yogyakarta: BPFE

Kasmir. (2010). Pengantar Manajemen Keuangan. Jakarta: Kencana Prenada Media Group.

Harmono. (2009). Manajemen Keuangan. Jakarta: PT. Bumi Aksara.

Priyatno, Duwi. (2012). Cara Kilat Belajar Analisis Data Dengan SPSS 20 Edisi Kesatu. Yogyakarta: ANDI.

Sugiyono. (2010). Metode Penelitian Bisnis. Bandung: Alfabeta.
Sulistyanto, Sri. (2011). Manajemen Laba: Teori Dan Model Empiris. Jakarta: Grasino.

Greening, Hennie Van. Scott, Darrel dan Terblanche, Simunet. (2013). International Financial Reporting Standards Edisi 6. Jakarta: Salemba Empat.

Prastowo, Andi. (2011). Metode Penelitian Kuantitatif Dalam Perspektif Rancangan Penelitian. Ypgyakarta: Ar-Ruzz Media.

Sutrisno. (2009). Manajemen Keuangan Teori Konsep Dan Aplikasi. Yogyakarta: Ekonisia.

Sartono, Agus. R. (2010). Manajemen Keuangan Teori Dan Aplikasi Edisi 4. Yogyakarta: BPFE.

Tendelilin, E. (2010). Portofolio Dan Investasi Teori Dan Aplikasi Edisi Pertama. Ypgyakarta: KANISIUS.

Tryfino. (2009). Cara Cerdas Berinvestasi Saham Edisi I. JAKARTA: Transmedia Pustaka.

Harahap, Sofyan Sahri. (2010). Analisis Kritis Atas Laporan Keuangan. Jakarta: Rajawali Persada.

\section{INTERNET}

www.idx.co.id

www.plazaindonesiarealty,com

www.sahamok.com

www.idnfinancials.com 